\title{
Principles of Good Practice in SoTL
}

\begin{abstract}
For the Scholarship of Teaching and Learning (SoTL) to be understood as significant intellectual work in the academy, SoTL practitioners need to identify shared principles of good practice. While honoring the diversity of SoTL in its many forms across the globe, such principles can serve as a heuristic for assessing work in our field. These principles include (1) inquiry into student learning, (2) grounded in context, (3) methodologically sound, (4) conducted in partnership with students, and (5) appropriately public. Taken together, these five principles can be guideposts for developing and refining individual SoTL inquiries and larger SoTL initiatives. These principles also can clarify and demystify SoTL to those on our campuses who evaluate our work, helping us to make the case for institutional resources and support for SoTL. Even more importantly, these principles articulate a vision of a scholarship that enhances, perhaps even transforms, teaching and learning in higher education.
\end{abstract}

\section{KEYWORDS}

principles, practice, quality, evaluation, methods, students

In the United States, the Scholarship of Teaching and Learning (SoTL) tends to be classroom-oriented, rather than theory- or hypothesis-driven. Faculty often start with "a teaching problem" (Bass, 1999), a discipline-based question linked to what they see in the learning, or the misunderstandings, of their own students. This inductive, grounded approach emerges in part because faculty often learn and practice SoTL on their own or with colleagues in ad hoc professional development settings, not being trained in graduate school or in post-graduate coursework on learning sciences and educational research (Sorcinelli et al., 2005). The amateur culture often makes US SoTL more of a methodological and theoretical mutt than its cousins from other countries, such as Australia and the United Kingdom (Bernstein, 2010).

While this diversity has allowed SoTL to develop and grow widely in the US and across the world, it also has produced a kind of inconsistency, perhaps even incoherence, that makes it difficult to evaluate the quality of SoTL inquiries - particularly as the international SoTL community develops. This is no small problem. As Bernstein argues, "When we describe teaching as serious intellectual work or scholarship, we need to prove that the products of teaching can also be rigorously evaluated for excellence by a community of peers" (2008, p. 51).

Scholarly peer review typically builds on disciplinary norms about the means and 
markers of excellence. In SoTL, however, shared definitions are elusive (Woodhouse, 2010; Potter \& Kustra, 2011) and perhaps not even desirable if we value the classroom focus that has benefited the evolution of SoTL. And even for the best, most rigorous SoTL projects, the appropriate location for and approach to "going public" can be uncertain. Huber notes (2009), for example, that influential SoTL in the US often has not appeared in traditional scholarly venues, but rather flowed through less formal networks of scholars inquiring into student learning. For these reasons, the SoTL community cannot and should not rely exclusively on the typical method of judging scholarly quality, publication in top-tier peer-reviewed journals.

These limitations, however, must not prevent us being able to make distinctions about quality in SoTL. For scholarly inquiry into student learning to be recognized as significant intellectual work in the academy, we (the community of practitioners) need to articulate our shared norms, our common principles of good practice of inquiry into student learning. These principles should reflect the essential characteristics of exemplary work (Trigwell et al., 2000), and they should echo foundational claims about the nature and practice of SoTL, including Boyer and Shulman, Hutchings and Huber. These principles should not be applied bluntly, but rather should allow for the range of scholarpractitioners across the full "continuum from classroom inquiry to rigorous educational research" (Bernstein, 2010). While honoring the diversity of SoTL in its many forms across the globe, principles of good practice can serve as a heuristic for understanding and evaluating work in our field.

\begin{tabular}{|c|}
\hline Principles of Good Practice in SoTL \\
\hline Inquiry focused on student learning \\
\hline Grounded in context \\
\hline Methodologically sound \\
\hline Conducted in partnership with students \\
\hline Appropriately public \\
\hline
\end{tabular}

The first principle of SoTL, of course, is inquiry focused on student learning. Learning should be understood broadly to include not only disciplinary knowledge or skill development, but also the cultivation of attitudes or habits that connect to learning. Inquiry into learning usually focuses on students, but it also can include explorations of how a teaching and teachers influence student learning (Biggs, 1999). The kinds of questions that drive inquiry into learning will vary, ranging across the disciplines (Huber \& Morreale, 2002) and across Hutchings' taxonomy from "what works" and "what is" to visions of the possible and theory building (2000). While allowing for broad definitions and diverse questions, quality inquiry must have clear goals and be critically reflective (Glassick et al., 1997). Thus, good practice in SoTL requires focused, critical inquiry into a well-defined aspect of student learning.

Similarly, good practice is grounded in both scholarly and local context. Scholarship of any type builds on what is known, using relevant theory, practice-based literature, and prior research to establish a firm foundation for inquiry (Glassick et al., 1997). For SoTL, attention to context also requires sensitivity to the location and dynamics of the inquiry, since all SoTL is rooted in particular classroom, disciplinary, institutional 
and cultural contexts (Hutchings \& Huber, 2005). Considerations of good practice in SoTL also should be cognizant of the different environments of faculty work. Some of us teach large numbers of students, making quantitative methodologies more possible than for those of us who teach small classes (Peters et al., 2008); some of us have very heavy teaching loads and little research support, while others have more time and resources to support our work. Any measure of good practice must account for both the scholarly and the local context where that work is being done.

Third, good practice in SoTL is methodologically sound. From its beginnings in the United States, SoTL practitioners have struggled with methodological questions. Huber and Morreale (2002) made the case for "disciplinary styles" within the movement, recognizing how different disciplines incline faculty toward different questions and distinct ways of collecting and analysing evidence of student learning. At the same time, social science research methods became particularly influential, in no small part because these approaches had been developed by experts to study learning and development. Authors of helpful guides to SoTL practice, such as McKinney (2007), have identified a smorgasbord of SoTL methods that have been used extensively in the United States. However, arguments in favor of discipline-specific methods continue to resonate (e.g., Bass \& Linkon, 2008). Regardless of the methods employed, good practice in SoTL requires the intentional and rigorous application of research tools that connect the question at the heart of a particular inquiry to student learning.

Fourth, good practice requires that inquiry into learning be conducted in partnership with students. At a minimum, SoTL must follow the basic tenets of human subjects research, ensuring that students are not harmed and that participants understand their rights (Hutchings, 2000). Beyond that baseline, however, partnering with students in inquiry is becoming a more widely recognized component of effective SoTL. Building on the work of Carnegie Scholars like Carmen Werder, in 2005 Hutchings and Huber urged the expansion of the "teaching commons" to include students. They deepened that call later to emphasize the need for "a commitment to more shared responsibility for learning among students and teachers, a more democratic intellectual community, and more authentic co-inquiry" (Hutchings \& Huber in Werder \& Otis, 2010, p. xii). SoTL practitioners, often in partnership with students, have demonstrated the power and possibilities of such collaborative work (Werder \& Otis, 2010; Bovill et al., 2011). While full partnership may not be practical or appropriate in all SoTL projects, good practice requires engaging students in the inquiry process.

Finally, good practice involves "going public." For two decades, Shulman has emphasized this step as essential as a means of making teaching "community property." Trigwell and his colleagues have articulated a helpful model that includes four dimensions of "communication" about SoTL, beginning with "none" and progressing through local conversations with colleagues to reports at national conferences and ultimately "publication in international scholarly journals" (2000, p. 163). While much SoTL fits neatly within this model, Bernstein and Bass (2005) have made the case for less traditional formats for going public with SoTL inquiries, arguing that "Sustained inquiry into student learning across semesters that is made widely available in an electronic course portfolio is a high form of scholarship in its own right" (p. 42). Because SoTL inquiry typically is iterative and highly contextual, the most appropriate ways to go public should capture and reflect the evolving nature of this form of research. In many cases, that is not possible in 
a traditional scholarly journal. Regardless of the format, however, good practice in SoTL requires that both the process and the products of inquiry are public so that colleagues can critique and use the work.

Taken together, these five principles can be used as guideposts for developing and refining both individual SoTL inquiries and larger SoTL initiatives. A faculty member who is first dipping her toe into the SoTL waters can ask how each applies to her own question about student learning. More experienced colleagues can weigh the relative strengths and weakness of past or future inquiries by measuring each against the five principles. For those involved in broader SoTL programs, these principles encourage comparison and contrast across diverse projects and disciplines, perhaps even leading to the creation of a rubric that articulates locally defined standards of excellence on each of the five principles. As Gale (2008) persuasively argues, moving toward more collaborative inquiry is essential for SoTL to reach its full potential, although doing so will be difficult without losing the grass-roots approach to inquiry that has been the heartbeat of so much SoTL. These five principles of good practice may help colleagues and campuses work together across their differences by underscoring the common aspects of distinct inquiries.

Not only would guiding principles help us do our work, but they would also help clarify and demystify SoTL to those who evaluate this work. On many campuses, administrative and faculty colleagues may not understand scholarly inquiry into student learning, and some are skeptical of claims about a "scholarship" of teaching and learning. One way to change their minds is for SoTL practitioners to come together in articulating and upholding norms that reflect the best of our work. Principles of good practice can act as lenses for them, and for us, focusing on what we already do well, and establishing vision for what we aspire to do. Shaping that vision is essential for making the case for institutional resources and support for our work, and even more importantly, for upholding our professional obligations as teacher-scholars.

Peter Felten is assistant provost and executive director of the Center for Engaged Learning and the Center for the Advancement of Teaching \& Learning, and an associate professor of history at Elon University.

\section{REFERENCES}

Bass, R. (1999). The Scholarship of Teaching: What's the Problem? Inventio http://doit.gmu .edu//archives/feb98/randybass.htm.

Bass, R. \& Eynon, B. (Eds.) (2009). New media technologies and the scholarship of teaching and learning. The Academic Commons (January). http://www.academiccommons.org /issue/january-2009.

Bernstein, D.J. (2008). Resource review: Peer review and evaluation of the intellectual work of teaching. Change, 40(2), 48-51.

Bernstein, D. (2010). Finding your place in the scholarship of teaching and learning. International Journal for the Scholarship of Teaching and Learning 4(2).

Bernstein, D. \& Bass, R. (2005). The scholarship of teaching and learning. Academe, 91 (4), 37-43.

Biggs, J. (1999). What the student does: Teaching for enhanced learning. Higher Education Research \& Development 18(1), 57-75. 
Glassick, C.E., Huber, M.T., \& Maeroff, G.I. (1997). Scholarship assessed: Evaluation of the professoriate. Hoboken, NJ: Jossey-Bass.

Gale, R. (2008). Points without limits: Individual inquiry, collaborative investigation, and collective scholarship. In D.R. Robertson \& L.B. Nelson (Eds.), To improve the academy: Resources for faculty, instructional, and organizational development, 26 (pp. 39-52). San Francisco: Jossey-Bass.

Huber, M.T. (2009). Teaching travels: Reflections on the social life of classroom inquiry and innovation. International Journal for the Scholarship of Teaching and Learning 3(2).

Huber, M.T., \& Hutchings, P. (2005). The advancement of learning: Building the teaching commons. San Francisco: Jossey-Bass.

Huber, M.T. \& Morreale, S.P., eds (2002) Disciplinary Styles in The Scholarship of Teaching and Learning: Exploring Common Ground. Washington, DC: American Association for Higher Education and The Carnegie Foundation for the Advancement of Teaching.

Hutchings, P., (2002). Ethics of Inquiry: Issues in the Scholarship of Teaching. Palo Alto, CA: Carnegie Foundation for the Advancement of Teaching.

Hutchings, P. (2000). Opening Lines: Approaches to the Scholarship of Teaching and Learning Palo Alto, CA: Carnegie Foundation for the Advancement of Teaching.

Hutchings, P., Huber, M. T., \& Ciccone, A. (2011). The Scholarship of Teaching and Learning Reconsidered: Institutional Integration and Impact. San Francisco, CA: Jossey-Bass.

McKinney, K. (2007). Enhancing learning through the scholarship of teaching and learning: the challenges and joys of juggling. San Francisco: Jossey-Bass.

Peters, D., Schodt, D., \&Walczak, M. (2008). Supporting the scholarship of teaching and learning at liberal arts colleges. In D.R. Robertson \& L.B. Nelson (Eds.), To improve the academy: Resources for faculty, instructional, and organizational development, 26 (pp. 39-52). San Francisco: Jossey-Bass.

Potter, M.K., \& Kustra, E. (2011). The relationship of scholarly teaching and SoTL: Models, distinctions, and clarifications. International Journal of the Scholarship of Teaching and Learning, 5(1).

Shulman, L. (2004). Teaching as Community Property: Essays on Higher Education. San Francisco, CA: Jossey-Bass.

Sorcinelli, M.D., Austin, A.E., Eddy, P.L., \& Beach, A.L. (2006). Creating the future of faculty Development: Learning from the past, understanding the present. Bolton, MA: Anker.

Trigwell, K., Martin, E., Benjamin, J., and Prosser, M. (2000). Scholarship of teaching: A model. Higher education research and development, 19 (2): 155-168. Retrieved from www.clt.uts. edu.au/Scholarship/A.Model.html.

Werder, C. \& Otis, M., eds. (2010). Engaging Student Voices in the Study of Teaching and Learning. Sterling, VA: Stylus.

Woodhouse, R. (2010). "Hype or hope: Can the scholarship of teaching and learning fulfill its promise?" International Journal for the Scholarship of Teaching and Learning 4:1. 